\section{Evolution on the mind}

$S_{i R}$ - Although I - probably like many of your readers - do not quite see why Waller's five-wish 'evoholics' should be so different from Dawkins' selfish geniuses in practice (since the selfish gene model in no way precludes the evolution of genes for each of the five 'wishes' Waller lists), it nevertheless seems worthwhile to point out that psychoanalytical insights might be added to the list of the "various research findings" which Waller claims have "shown that all the 'gifts' which I have hypothetically given to my heirs actually exist" - at least among human beings ${ }^{1}$.

For example, the unconscious sexual and aggressive wishes uncovered by psychoanalytical investigations in general, and freudian dream-interpretation in particular, might easily follow Waller's first wish (continual assessment of performance regarding genetic replication), and his second (a sense of well-being as a motivator, especially in stimulating "libido" - Waller's own term), seems to be Freud's "pleasure principle"2,3. Psychoanalytical insights into mania as a defence against depression would certainly illustrate his third wish (reactive responses to depression), and his fourth (self-elimination in the event of failure) is perhaps the real biological foundation for Freud's hypothesized - and, until now, seemingly biologically absurd - "death instinct"

As far as Waller's final wish (a genetic basis for differing character types) is concerned, freudian findings regarding the importance of childhood identifications may provide illustrations in profuse detail. To take just one example, the widely reported finding from both conventional, academic psychology ${ }^{5}$ and psychoanalysis that fathers appear to be critical in determining the sex role of sons may in reality reflect a specific example of this fifth wish: one in which sons estimate the likelihood of their having inherited genes for a successful male sex role by means of identification (that is, phenotypic matching by psychological self-comparison) with an adequate father-figure, or otherwise as the case may be ${ }^{6}$.

Although Waller may well be as reluctant to recognize such freudian proclivities in his hypothetical offspring as parents frequently are to admit comparable evidence of genetic self-interest in themselves and their children, Freud for his part would probably have claimed honorary membership in the guild of selfish-gene psycho-darwinists on the strength of his assertion that "the individual organism, which regards itself as the main thing and its sexuality as a means, like any other, for its own satisfaction, is from the point of view of biology only an episode in a succession of generations, a short-lived appendage to a germ-plasm endowed with immortality - like the temporary holder of an entail which will outlast him" 7

Indeed, Freud's real offence may have been to discover and describe the actual manifestations of this in human beings, rather than merely to speculate in general terms as Waller and others have done.

\section{Department of Sociology,} Christopher Badcock

London School of Economics

London WC2A $2 A E$, UK

1. Waller, M. J. C. Nature 351. 264 (1991)

2. Barash, D. Sociobiology: The Whisperings within (Souvenir Press, London, 1979).

3. Badcock, C. R. Evolution and Individual Behavior: (Blackwell, Oxford 1991).

4. Badcock, C. R. Essential Freud: An Introduction to Classical Psychoanalysis 2nd edn (Blackwell, Oxford, in the press).

5. Lamb. M. The Role of the Father in Child Development (Wiley, New York, 1981)

6. Badcock, C. R. Oedipus in Evolution: A New Theory of Sex (Blackwell, Oxford, 1990).

7. Freud, S. Introductory Lectures on Psychoanalysis, $\mathbf{x x V}$. 413-414. (Hogarth Press and the Institute of Psycholanalysis, London, 1963).

SIR - I found M. J. C. Waller's psycho-darwinist hypothesis of evolution very sobering, particularly in the light of my scientific interests as a pharmacologist working on the central nervous system. It appears to me that all we need do is wait for mother nature to eradicate CNS disorders of mood and eventually put the likes of me out of business. In a more serious approach to this theory, I feel a little concerned for the future of mankind. Many artists seem to have suffered from some kind of affective disorder, which would eventually push them out of the gene pool, and leave the remaining happy humans without much in the way of emotional and spiritual expression. It also occurs to me that, in most cases, depressive illness, like many other CNS disorders, appears to strike after most people have had their heirs (median age for depression is 40 , and for bipolar disorders about 30 ). Thus, the pyscho-darwinist theory, if it were true, would have little influence on the evolution of mankind.

\section{Royal Free Hospital School of}

\section{Medicine,}

London NW3 2PF, UK

SIR - M. J. C. Waller's thought-experiment (he and I as the only males on an otherwise all-female planet) has undeniable appeal. But alas, like many such fantasies, it has no connection with reality.

He imagines that we are each offered the opportunity to force our remote descendants to behave in certain ways so as to improve the 'evolvability' of our posterity. $\mathrm{He}$ would eagerly seize the opportunity and would, for example, require his descendants to sacrifice themselves, if they sensed that they were unsuccessful, for the good of their 'kind'. I, on the other hand, should honourably decline the offer, "confident that the selfish gene model cannot be improved upon".

Of course the selfish gene model can be improved upon. It is easy to see that an allpowerful dictator, with the interests of some larger community at heart, could improve upon it. You name an interested group - the Coast Redwood forests, the world's whale population, albinos - and I'll specify an 'improvement' to the selfish gene theory that would benefit that group. The problem is not that one can't think of improvements from some named point of view. The whole problem is that those improvements will not be evolutionarily stable. They'll disappear under natural selection because the only point of view natural selection cares about is that of the replicating entities - the selfish genes.

Waller correctly discerns that his thoughtexperiment has something to do with group selection. Unfortunately it solves none of the notorious problems of group selection. If the set of all Waller's descendants could somehow be delimited as a watertight group, he might (just) have some hope of making a form of group selection work. But of course his descendants on the planet, far from being watertight, would pretty soon also be my descendants. Neither Waller nor I would be entitled to label our remote descendants as our 'kind' rather than the other patriarch's. His genes and mine would shuffle and reshuffle down the generations. In such a world of reshuffling replicators, the only interests that natural selection can favour are the interests of the replicators themselves.

There is a realistic sense in which lineages may be selected for improved 'evolvability', but it is very different from Waller's sense. I have spelled it out in my paper 'The evolution of evolvability'.

Richard Dawkins

Department of Zoology

South Parks Road,

Oxford OX1 3PS, UK

Dawkins, R. in Artificial Life (ed. Langton, C.) 201-220 (Addison Wesley, Sante Fe, 1989).

\section{Snow's way with cholera}

SIR - It was indeed John Snow who, in August 1854, investigated the cholera epidemic in the area around Broad Street ${ }^{!}$. He later wrote: "The result of the inquiry then was, that there had been no particular outbreak or increase of cholera, in this part of London, except among the persons who were in the habit of drinking the water of the [Broad Street] pump-well ... I had an interview with the Guardians of St James's parish, on the evening of Thursday, 7th September.... In consequence of what I said, the handle of the pump was removed the following day." 2

University of Georgia,

Brian Mooney

Savannah River Ecology Laboratory,

Aiken, South Carolina 29802, USA

1. Butloch. W. The History of Bacteriology 167-168 10xford University Press. London. 1938

2. Snow. J. On the Mode of Comimunication of Cholcra Reprinted in Source Book of Medical History led. Clendening. L.) 468-473 (Dover. New York. 1960 ). 